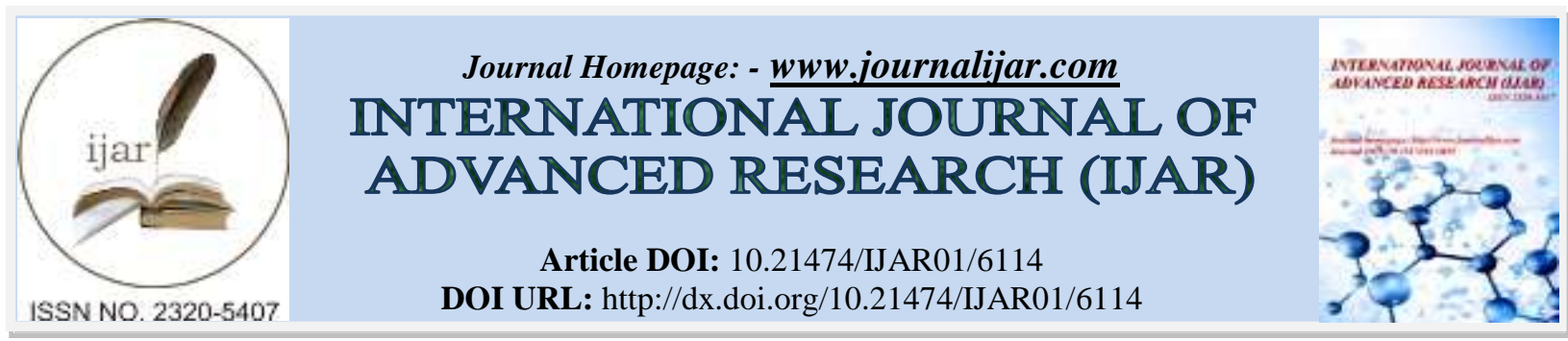

RESEARCH ARTICLE

\title{
MESOZOIC BASALTIC MAGMATISM OF THE SIDI SAÏD MAACHOU BASIN (WESTERN MESETA, MOROCCO): PETROGRAPHY, GEOCHEMISTRY AND GEODYNAMIC IMPLICATIONS.
}

\section{Abdelkbir Hminna ${ }^{1}$, Hafid Saber ${ }^{2}$ and Abdelouahed Lagnaoui ${ }^{2}$.}

1. Department of Geology, Sidi Mohamed Ben Abdellah University, Dhar El Mahraz, B.P. 1796, Fès-Atlas, 30003, Morocco.

2. Department of Geology, Chouaïb Doukkali University, Faculty of Sciences, B.P. 20, El Jadida, 24000, Morocco.

\section{Manuscript Info}

(.........................

Manuscript History

Received: 20 October 2017

Final Accepted: 22 November 2017

Published: December 2017

Key words:-

Petrology; Geochemistry; Upper Triassic; Coastal Meseta; Central Atlantic Magmatic Province (CAMP) .

\section{Abstract}

The late Triassic-early Jurassic volcanism of Sidi Saïd Maachou basin belongs to the costalMeseta and the Central Atlantic Magmatic Province (CAMP). The volcanic pile conformably overlies the red siltstones of Machraa Boujamaa Formation. This set includes a stack of several lava flows 40 to $80 \mathrm{~m}$ thick. The petrographic study shows that the textures vary from porphyritic to microlitic porphyritic. These igneous rocks have the geochemical characteristics of an intracontinental tholeiitic series of an anorogenic context announcing the Triassic distension. On the basis of their petrographic and geochemical characteristics, the lava flows of Sidi Saïd Maachou tholeiitic basalts approach those of the Triassic Basin of Berrechid-El Gara-Benslimane and the High Atlas. With these data, we attempt to place these volcanic rocks in global geodynamic context by making comparisons with other Upper Triassic-Early Jurassic volcanic rocks genetically related to the breakup of Pangea and the Central Atlantic Magmatic Province resulting from thinning of continental lithosphere.

Copy Right, IJAR, 2017,. All rights reserved.

\section{Introduction:-}

In Morocco, the end of Triassic ( $200 \mathrm{Ma})$ is marked by large deposits of tholeiitic basalts during the final stages related to the rifting of the Central Atlantic Magmatic Province (CAMP) (Marzoli et al., 1999). In the Western Meseta, and in particular in the Sidi Saïd Maachou basin (Fig. 1), only a few studies have been carried out (Peretsman, 1985; Girard, 1987; Peretsman and Holser, 1988; Girard et al., 1989; Lyazidi et al., 2003; Bensalah et al., 2011; Farki et al., 2014). This strongly contrasts with the abundant scientific literature on volcanic rocks existing for the other basins in Morocco, such as those of the High Atlas (Termier, 1948; Verdier, 1971; Bertrand et al, 1982; De Pachtère et al., 1985; Bertrand, 1991; Ait Chayeb et al., 1998; Youbi et al., 2003; Knight et al., 2004; Marzoli et al., 2004; Verati et al., 2007; Font et al., 2011; El Hachimi et al., 2011), of the Middle Atlas (Charière, 1990; Fiechtner et al., 1992; Hamidi et al., 1997; Lachkar et al., 2000; Ouarhache, 2002; Mahmoudi and Bertrand, 2007), and of Central and Eastern Morocco (Cogney et al., 1971, 1974 ; Cogney and Faugères, 1975 ; El Wartiti, 1981).

This work is a contribution to the knowledge of CAMP magmatism of the Moroccan coastal Meseta, presenting new petrographic and geochemical data on the Sidi Saïd Maachou basin. 


\section{Geological setting:-}

The approximately $40 \mathrm{~km} 2$ study area, named after its village Sidi Saïd Maachou, is located in the coastal uplift of the Moroccan Western Meseta about $46 \mathrm{~km}$ South-East of El Jadida city (Fig. 1). Geological interest of this domain is based on numerous outcrops of pre-Cenozoic rocks along the Oued Oum Er Rbiaa valley. Along the Northern, Eastern and South-Eastern border of the area, Triassic sediments unconformably overlie Palaeozoic (Cambrian and Devonian) basement. To the West and South-West,

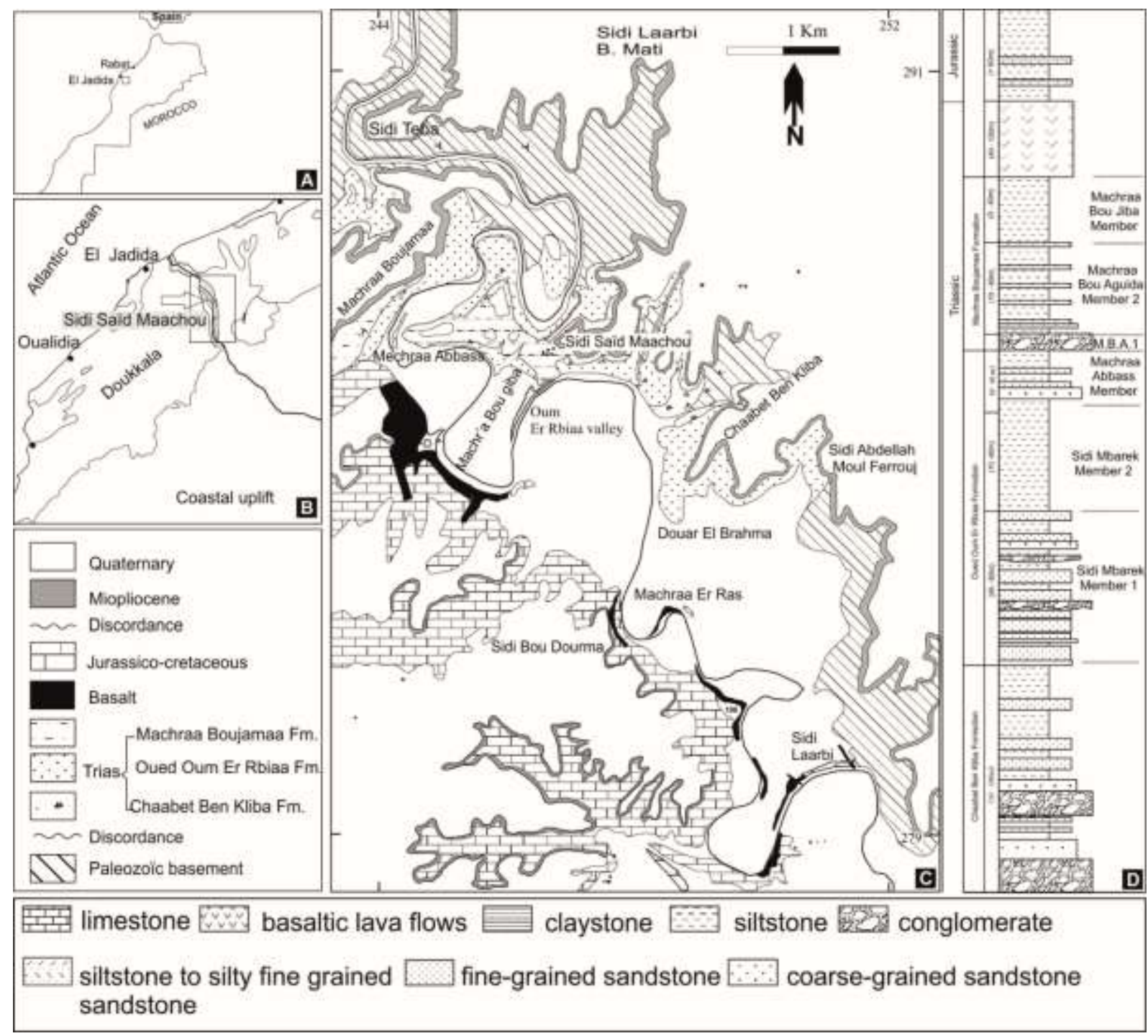

Figure. 1:- Location and geological overview of the study area. A \& B- Position of the Sidi Saïd Maachou area in Morocco and the Western Meseta. C- Simplified geological map of the Sidi Saïd Maachou area. DLithostratigraphical profile of the Sid Said Maachou basin.

Triassic sediments are overlain by Rhaetian-Sinemurian tholeiitic basalts and Jurassic-Cretaceous sedimentary rocks (Gigout, 1956; Ouadia, 1998; Saber et al., 2007 ; Hminna et al., 2008 ; Bensalah et al., 2011 ; Hminna, 2013; Hminna et al., 2013). During the Early Mesozoic, accumulation of continental deposits took place in the Sidi Saïd Maachou area due to local subsidence most likely triggered by reactivated Late Palaeozoic faults.

The Sidi Saïd Maachou area (Fig. 1) is characterized by succession of red-beds about $500 \mathrm{~m}$ thick. Hminna et al. (2013) proposed a subdivision of the succession in seven lithostratigraphic units assigned to three formations (Fig. 1C, D). These formations are, from base to top: the basal Chaabet Ben Kliba Formation (10-100 m thick), The Oued Oum Er Rbiaa Formation (50-160 m thick), and the Machraa Boujamaa Formation (10-130 m thick). Each of these 
is separated from older strata by either an angular or erosional unconformity.

The basal Chaabet Ben Kliba Formation consists of debris-flow conglomerates. They were deposited as alluvial fans, sandstones and siltstones according to Miall (1996), grading vertically into distal alluvial-fan to alluvial-plain and maybe floodplain sandstones and siltstones (Miall, 1996) and soil formation in overbank fines siltstones.

The Oued Oum Er Rbiaa Formation is represented by braided alluvial plain sandstones and mudstones (Sidi Mbarek Member 1), wet mudfla mudstones and siltstones (Sidi Mbarek Member 2), and shallow lacustrine laminated mudstones (playa lake system) (Machraa Abbass Member). The upper Machraa Boujamaa Formation starts with alluvial-fan conglomerates (Machraa Bou Aguida Member 1: M.B.A. 1, Fig. 1D) that grade into increasingly finegrained sandstone-siltstone cycles. Those cycles record the transition into alluvial and floodplain deposition (Machraa Bou Aguida Member 2) and gypsiferous mudstones which are typical playa sediments that are probably formed under semiarid to arid climatic conditions.

The Triassic sedimentary succession of the Sidi Saïd Maachou area is crowned by up to $80 \mathrm{~m}$ thick tholeiitic basalts that unconformably overlie slightly deformed mudstones. Based on tetrapod footprints of Brachychirotherium parvum, Hminna et al. (2009, 2013) concluded a Late Triassic age (Carnian-Rhaetian) for the upper part of the Oued Oum Er Rbiaa Formation.

During the Early Mesozoic, accumulation of continental deposits took place in the Sidi Saïd Maachou area due to local subsidence. It was most likely triggered by reactivated Late Paleozoic (Hercynian) structures such as the Sidi Laarbi fault. This fault reaches from the SE into the study area (Fig. 1C) and might continue to the North-Western corner, but it is covered by Mesozoic and Cenozoic deposits. Subsurface data are required to more precisely assess the dimension and tectonic structure of the Triassic strata in the Sidi Saïd Maachou area.

\section{Field observations:-}

In the Sidi Saïd Maachou area, a large number of profiles were realized through the well developed Triassic-Liasic basaltic pile from North to South along the Oum Er Rbiaa valley (Fig.1C). This makes it possible a good correlation and to specify the conditions for the emplacement of the product of this volcanic activity. However, we will limit the description to the most significant cuts. The stratigraphic data show a superposition of several flows lava intercalated between a lower red detrital strata with thin gypsiferous levels and higher red detrital layer alternating with limestone near the top (Fig. 2).

The base of the volcanic pile conformably overlies the red siltstones of Machraa Boujamaa formation. This set includes a stack of several lava flows that developed over a variable thickness from 40 to $80 \mathrm{~m}$. In some places, we observe the intercalation of sedimentary levels among the lavas. The bottom of these flows is characterized by onion-skin weathering. Towards the middle of this volcanic pile begins a complex of both hard and altered lavas intersected by basaltic dykes (10 to $15 \mathrm{~cm}$ in diameter; Fig. 2 and 


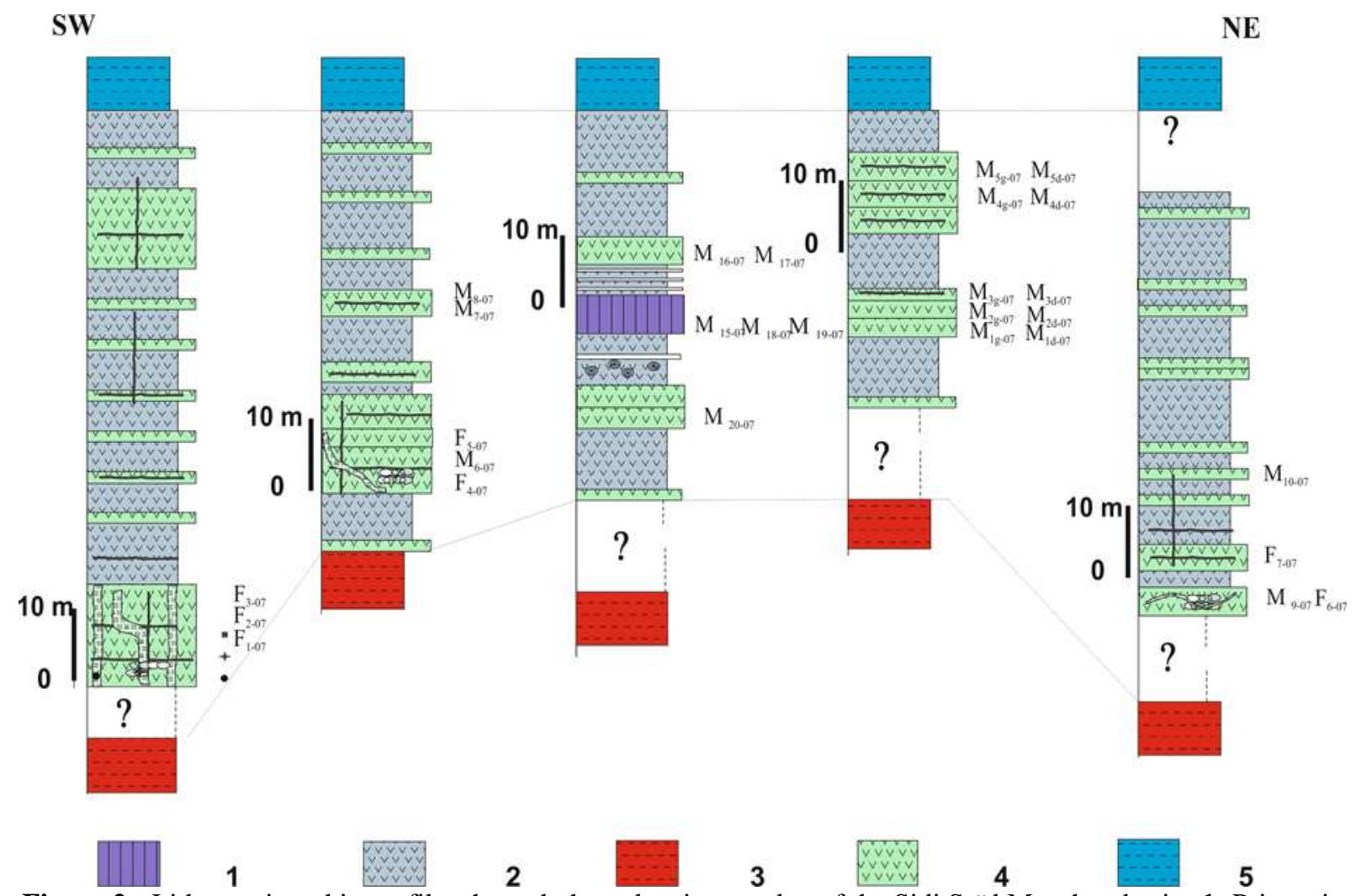

Figure 2:- Lithostratigraphic profiles through the volcanic complex of the Sidi Saïd Maachou basin. 1- Prismatic basalts. 2- Altered basalt. 3- Triassic red beds. 4- Basalt "little" altered. 5- Red silts and limestone of Jurassic. (M and F: Sample number)

3). These dykes are observed almost throughout the volcanic pile. They are hard, compact and arranged laterally, vertically or sometimes also in sinuous form (Fig. 3E and 3F) in relation to the volcanic lava flows. Silica veins are also present frequently. The assembly is surmounted by a succession of altered lavas flows, interrupted in its central part by a prismatic lava deposit of $2 \mathrm{~m}$ thick (Fig. 3C, D), which is disseminated into remarkable prisms or columns. The absence of pillow lavas and the presence of such prismatic flows are arguments in favor of sub-aerial conditions. Significant variations of thickness in volcanic profiles $(30$ to $80 \mathrm{~m})$ can be explained either by differential subsidence of the ante-volcanic substratum during the effusion of the flows or by settling of these lavas on a substratum already structured either in graben or half-graben structures.

\section{Petrographic study:-}

The basalts of Sidi Saïd Maachou are largely altered. Indeed, only a few samples were collected in relatively fresh or slightly altered levels. These basaltic rocks are characterized by three main textures: porphyritic, porphyritic intersertal to dolerite, and a slightly microlitic porphyry probably vacuolar microlitic texture.

Three volcanic facies are defined according to the textures of the rocks :

\section{Facies 1:-}

The rocks show a porphyritic microlitic texture, composed mainly of plagioclase, clinopyroxene, olivine and opaque minerals (Fig. 4A, B). The groundmass phases are represented by glass containing fine crystal of clear feldspars, and opaque minerals. 

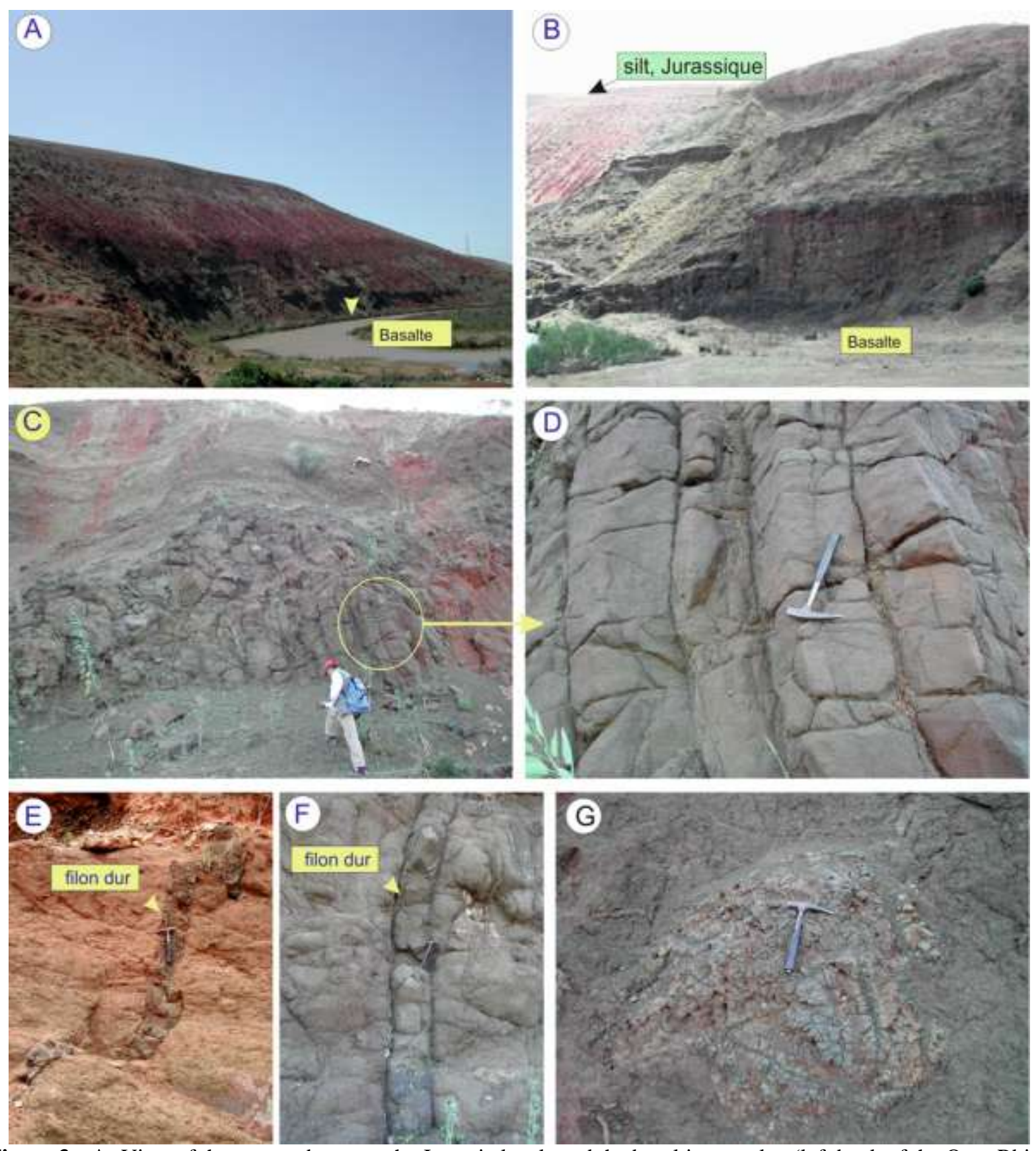

Figure 3:- A- View of the contact between the Jurassic levels and the basaltic complex (left bank of the Oum Rbiaa valley). B- Outcrop of superimposed basaltic lava flows showing hard levels and altered soft levels. C- Prismatic basalt. D- Detail of prismatic basalt. E-F - Late consolidated basalt dykes intersecting highly altered basaltic levels observed south of the basin. G- Basaltic alteration in onion structure. 

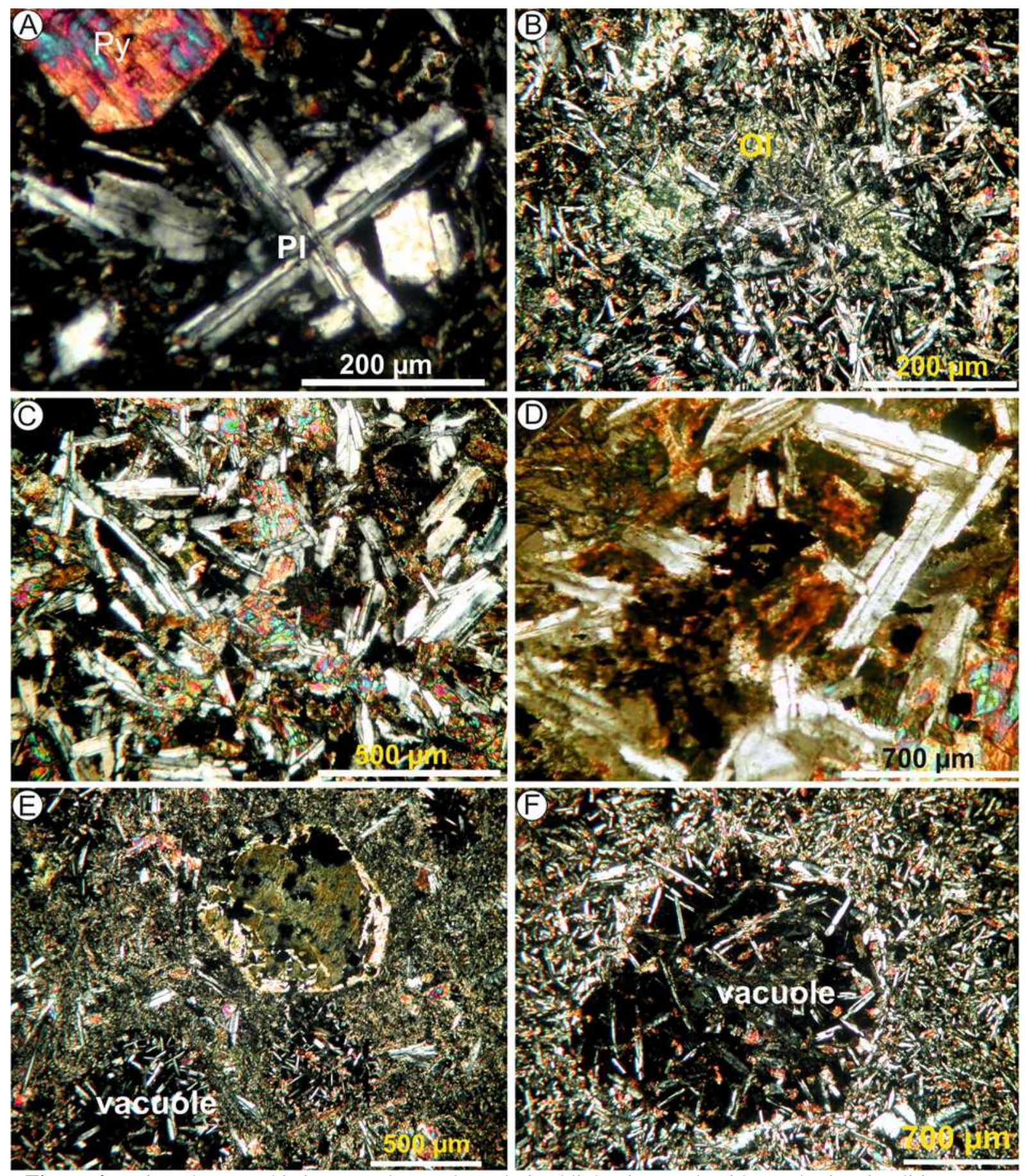

Figure 4:- Microphotographic images taken under polarized light: A- Basalt with porphyric microlitic texture (doleritic); B- Basalt with olivine gosth, completely transformed into chlorite (porphyric microlitic texture); C \& DBasalt with a porphyric microlitic texture with doleritic tendency; $\mathbf{E} \& \mathbf{F}$ - Basalt with a porphyric microlitic vacuolar texture.

Olivine accounts for about $8 \%$ of the total volume of the rock. Its size varies from 0.2 to $1 \mathrm{~mm}$. It appears as euhedral to subhedral crystals, sometimes isolated but more often grouped in clusters. During hydrothermal alteration, it is completely transformed in either chlorite or iddingsite. However, the preservation of their shape is generally easy to recognize. 
Pyroxene represents approximately $25 \%$ of the total volume of rock. The crystals are subhedral with sizes from 0.1 to $0.7 \mathrm{~mm}$. They appear intact and show augite optical characteristics. It exhibits a change in color, may be due to a chemical zoning.

Plagioclase is the most dominant phase (40\%). It comes in laths $\sim 0.1$ to $0.7 \mathrm{~mm}$ long, either as phenocrysts with polysynthetic twins or as microlithes. Some of them are included in the pyroxene. Sometimes it has a symplectic structure, which suggests that these rocks may be the result of a fractional crystallization process.

Opaque minerals are very abundant (approximately 20\%) and are present either in small crystals, square to subrounded, or sometimes in sharp crystals and skeletal appearance indicating fast cooling.

The mesostasis corresponds to a cryptocrystalline or microcrystalline material. It generally consists of a multitude of microlites and ferromagnesian plagioclase.

\section{Facies 2}

This type of basalts presents a porphyry dolerite texture to intersertal whose crystal size reaches a few hundred microns (Fig. 4C, D). The mineral paragenesis is composed of plagioclase, pyroxene and opaque minerals.

Plagioclase is the predominant mineral in these rocks (50\%). They appear as phenocrysts (40\%) and as subhedral microlites (less than 5\%) which sometimes they overlap phenocrysts of pyroxene.

Occasionally plagioclase is partially transformed into sericite.

Pyroxene is less abundant than plagioclase and appears as anhedral to subhedral phenocrysts (10\%) and also as microlites (8\%). Some are twinned and chloritized the center and the rim. Some are transformed completely into chlorite.

Opaques are abundant and are represented by ilmenite and/or magnetite. They form, along small crystals of plagioclase and pyroxene, the rest of the groundmass. The matrix is also characterized by the presence of reddish glass, filling the interstices between the crystalline minerals.

\section{Facies 3:-}

The basalts of this facies are characterized by show microlitic vacuolar texture. The lava flow of particular composition shows generally the vacuoles clogged with opaque and plagioclase (Fig. 4E, F). The whole rock is formed by plagioclase microlites embedded in a fine-grained groundmass made up of plagioclase, pyroxene (present also as phenocrysts: $5 \%$; and microlites: $50 \%$ ) and opaque minerals.

Vacuoles occur in large subhedral cavities formed by expanding gas. They are clogged with phenocrysts of plagioclase and pyroxene.

\section{Geochemical study:-}

The geochemical study performed in the magmatic rocks of Sidi Saïd Maachou area aims at determining their chemical characteristics and magmatic affinity. The chemical analyses (major and trace elements) performed on seven samples of volcanic rocks of Sidi Saïd Maachou area are reported in table 1 . The dosage of the chemical elements was performed by X-ray fluorescence (XRF) at Laboratory of Geochemistry, Department of Geology, Faculty of Sciences, Chouaïb Doukkali University, El Jadida (Morocco).

The Triassic lava flows of Sidi Saïd Maachou area have the following characters:

- The silica content is relatively low (from 46.68 to $52.24 \%$ );

- Fire losses, ranging from 5 to $3.5 \%$, reflect the rather altered nature of these rocks;

- The concentrations of $\mathrm{TiO}_{2}(1.19-1.58 \%)$ and $\mathrm{P}_{2} \mathrm{O}_{5}(0.11$ to $0.20 \%)$ are low and comparable to those of MORB.

- The concentrations of $\mathrm{Nb}$ are particularly low compared to those of alkaline basalts ( $\mathrm{Nb}$ content of 0.7-15 ppm) and are similar to those of MORB and to a lesser extent to those of intraplate tholeiites.

- The concentrations of transition elements ( $\mathrm{Ni}, \mathrm{Cr}, \mathrm{Co}$ and $\mathrm{Sc}$ ) are generally very low and have small variations, respectively with intervals of 49-81 ppm, 220-355 ppm, 50-65 ppm and 29-44 ppm.

\section{Classification of rocks:-}

On the basis of the TAS diagram (Fig. 5A), analyzed samples are classified as sub-alkaline rocks (Irvine and 
Baragar, 1971; Miyashiro, 1978) and are mainly represented by basalts to basaltic andesites (Le Maitre et al., 1989). In the diagram of Winchester and Floyd (1976), which involves elemens considered as immobile during alteration and metamorphism ( $\mathrm{Ti}, \mathrm{Zr}, \mathrm{Nb}$ and $\mathrm{Y}$ ), the rocks plot in the field of subalkaline basalts (Fig. 5B).

These rocks are characterized by a low content of potassium $\left(\mathrm{K}_{2} \mathrm{O}: 0.48-0.99 \mathrm{wt} \%\right)$, which situate the majority of these rocks in the field moderately to weakly potassic "Low-K" defined by Peccerillo and Taylor (1976) and Gill (1981; Fig. 5C).
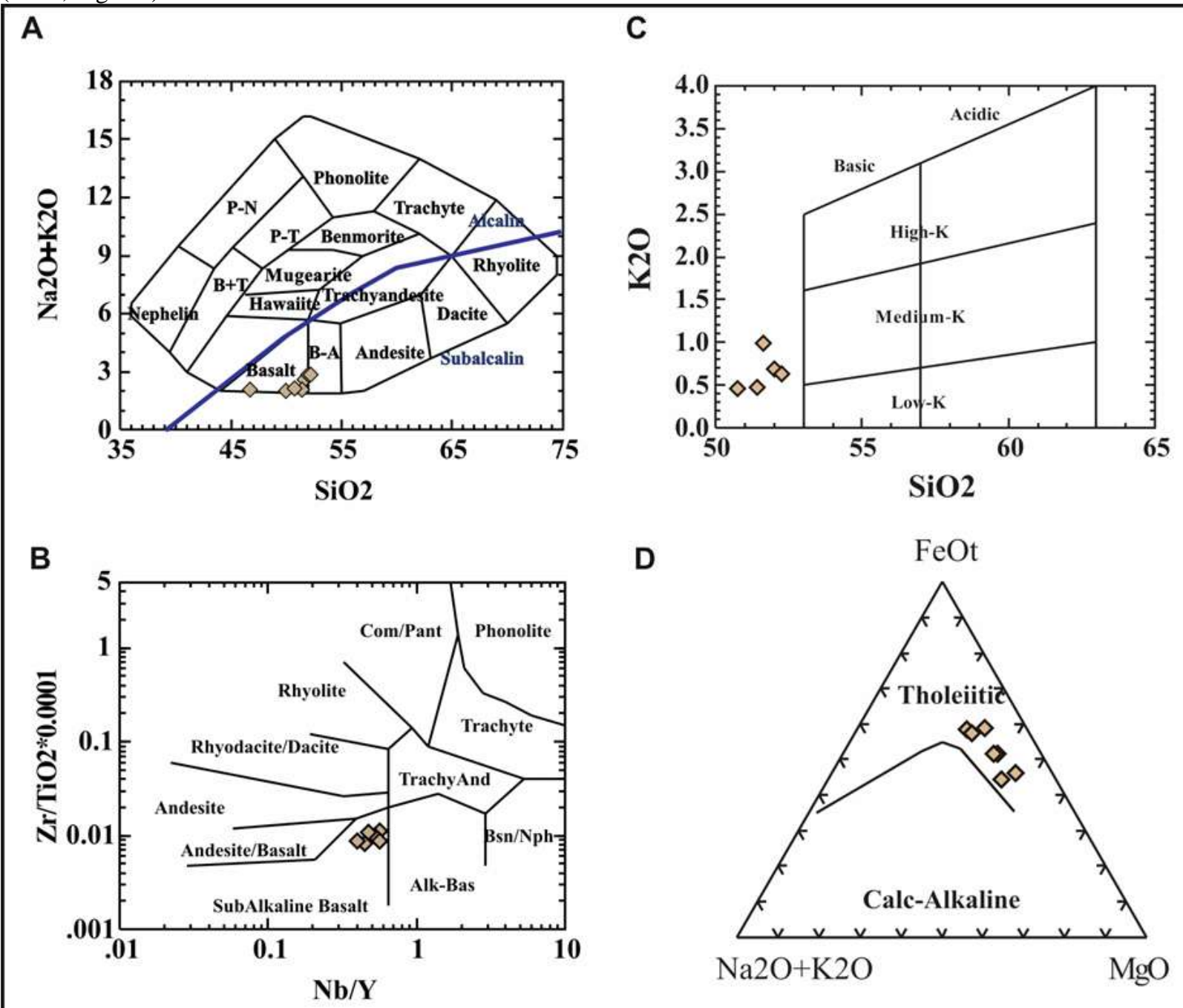

Figure 5:- A- Classification of the Sidi Saïd Maachou basin volcanic rocks in the Total alkali vs. $\mathrm{SiO}_{2}(\mathrm{TAS})$ diagram (Le Maitre et al., 1989). The continuous line separates the field of alkaline lavas from the subalkaline lavas

(Irvine and Baragar, 1971). B- Classification of altered magmatic rocks in the $\mathrm{Zr} / \mathrm{TiO}_{2} \mathrm{vs}$. $\mathrm{Nb} / \mathrm{Y}$ diagram of Winchester and Floyd (1976). C- Diagram of geochemical classification $\mathrm{K}_{2} \mathrm{O}-\mathrm{SiO}_{2}$ of Peccerillo and Taylor (1976) showing the weak to moderately potassic character of Triassic volcanic rocks. D- AFM diagram (Kuno, 1968) showing the tholeiitic character of Triassic magmatic rocks.

In order to determine the geochemical affinity of basalts in the study area, a number of discriminating triangular diagrams were used. This is the AFM diagram $\left(\mathrm{A}=\mathrm{Na}_{2} \mathrm{O}+\mathrm{K}_{2} \mathrm{O} ; \mathrm{F}=\mathrm{FeOt} ; \mathrm{M}=\mathrm{MgO}\right)$ of Nockolds and Allen (1956), $\mathrm{Al}_{2} \mathrm{O}_{3}-\mathrm{FeO}_{\mathrm{t}}-\mathrm{MgO}$ diagram of Besson and Fonteilles (1974).

The AFM diagram (Fig. 5D) separates the tholeiitic from calcalkaline evolutionary trends, mostly based on the different iron enrichment in the residual melts (Kuno, 1968). The studied rocks clearly plot in the tholeiitic field, being characterized by iron enrichment (Fig. 5D). 
We used the diagram of Miyashiro (1974) of $\mathrm{TiO}_{2}$ vs. FeOt/MgO (Fig. 6A). The FeOt/MgO ratio in the residual melt increases with the fractional crystallization. The chemical data projection of these rocks on the diagram of $\mathrm{TiO}_{2}$ according to $\mathrm{FeOt} / \mathrm{MgO}$ (Fig. 6A) shows a slight enrichment in the titanium during the differentiation of the characteristic of tholeiitic series. This diagram also separates the isotitanium field and the anisotitanium field characteristic of rocks of non-orogenic zones.

\section{Geotectonic Site:-}

Placed in the geotectonic discriminant diagrams (Fig. 6B, C and D), the Triassic lavas shows the characters of basalts with Anorogenic to sub-alkaline affinity. In the diagrams of Ti $\mathrm{O}_{2}-\mathrm{MnO}-\mathrm{P}_{2} \mathrm{O}_{5}$ (Mullen, 1983) (Fig. 6B), NbZr-Y (Meschede, 1986) (Fig. 6D), the representative points of the samples studied are mostly situate in the MORB area and/or intra-continental tholeiites.

The projection of these rocks on the $\mathrm{Zr} / \mathrm{Y}$ vs. Zr diagram, Pearce (1980), shows that the basalts of Sidi Saïd Maachou occupy largely the field of intraplate basalts (Fig. 6C).

A

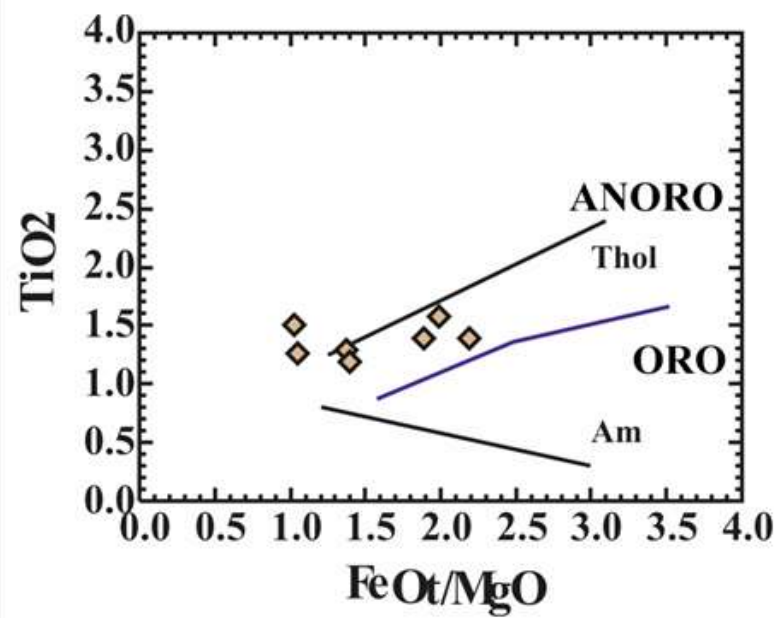

B

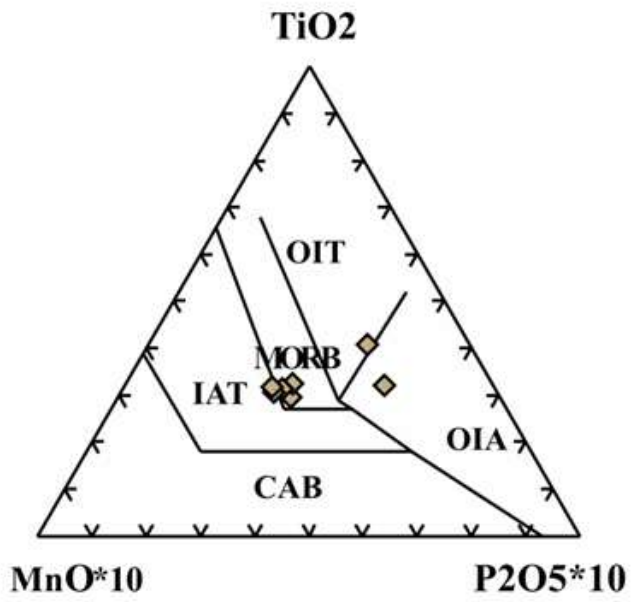

C

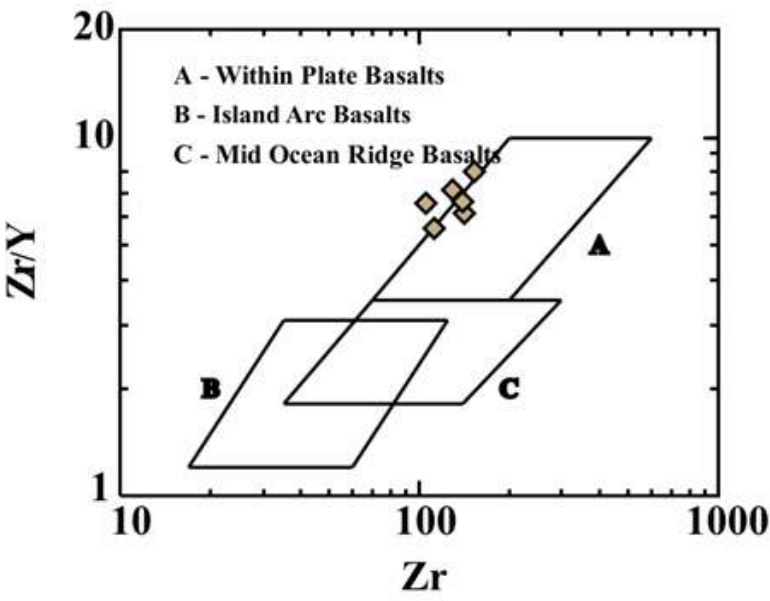

D

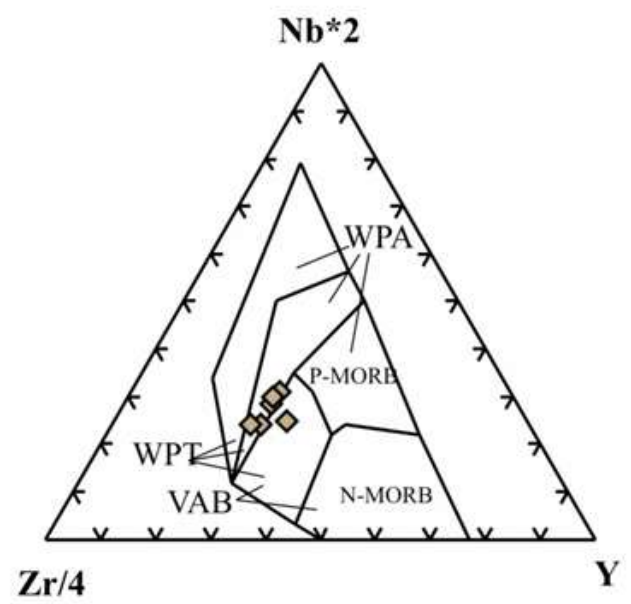

Figure 6:- A- Diagram of Miyashiro $(1974,1978)$ showing the tholeiitic character of the Triassic Sidi Saïd Maachou basin volcanic rocks. The blue line of discrimination of series (ORO) and anorogenic (ANORO) is after Bebien (1980). B- Distribution of the magmatic rocks in the triangular diagrams $\mathrm{TiO}_{2}-\mathrm{MnO}-\mathrm{P}_{2} \mathrm{O}_{5}$ of Mullen (1983); OIA: Ocean Island Alkali basalt; OIT: Ocean Island Tholeiite; MORB: Mid-Ocean Ridge Basalt; IAT: Island Arc Tholeiite; CAB: Calcalkaline basalt. C- Distribution of the magmatic rocks in the triangular diagram Nb-Zr-Y of 
Meschede (1986). VAB: Volcanic Arc Basalt; MORB, Mid-Ocean Ridge Basalt (N: Normal, P: Plume); WPA: Within Plate Alkaline Basalt; WPT: Within Plate Tholeiitic Basalt. D- Distribution of magmatic rocks in the Zr-

$\mathrm{Zr} / \mathrm{Y}$ diagram of Pearce (1980).

\section{Conclusion:-}

Petrographic and geochemical study of basaltic complex of Sidi Saïd Maachou area, consisting of stack doleritic and basaltic flows, clarifies the geochemical significance, magmatic affinity and geodynamic context of establishment of these basalts.

Petrographic study shows a porphyry to microlitic structure and texture.

The geochemical study (major and trace elements) allowed us to make the following conclusions:

- The igneous rocks have the characteristics of an intra-continental tholeiitic series.

- The magmatism is part of an anorogenic context announcing the Triassic distension.

This volcanism had close links with the opening of the central Atlantic, compared to diabase of the Eastern coast of North America (Bertrand and Westphal, 1977). For all their petrographic and geochemical characteristics, the lava flows of Sidi Saiid Maachou tholeiitic basalts approach those of the Triassic Basin of Berrechid-El Gara-Benslimane and the High Atlas.

With these data, we attempt to place these volcanic rocks in global geodynamic context by making comparisons with other Upper Triassic-Early Jurassic volcanic rocks genetically related to the breakup of Pangea and the Central Atlantic Magmatic Province resulting from thinning of continental lithosphere (CAMP, e.g., Marzoli et al.,1999, 2004 ; Callegaro et al., 2014).

\section{Acknowledgements:-}

The authors thank reviewers for constructive remarks and the journal's editor for helpful comments that improved this work. Also, many thanks to Faculty of Sciences of Chouaïb Doukkali University El Jadida for logistical support during field trips.

Table 1:- Analysis of major and trace elements of Triassic lava flows in the Sidi Saïd Maachou basin.

\begin{tabular}{|c|c|c|c|c|c|c|c|}
\hline $\begin{array}{c}\mathbf{N}^{\circ} \\
\mathbf{d}^{\prime} \text { échantillon }\end{array}$ & SM1-04 & SM2-04 & SM9-04 & SM10-04 & SM11-04 & SM12-04 & SM13-04 \\
\hline $\mathbf{S i O}_{\mathbf{2}}$ & 49.93 & 51.62 & 52 & 52.24 & 51.43 & 50.75 & 46.68 \\
\hline $\mathbf{A l}_{\mathbf{2}} \mathbf{O}_{\mathbf{3}}$ & 12.60 & 13.80 & 15.50 & 14.5 & 15.4 & 15.4 & 14.4 \\
\hline $\mathbf{F e}_{\mathbf{2}} \mathbf{O}_{\mathbf{3}}$ & 10.24 & 8.72 & 11.34 & 11.69 & 10.2 & 9.593 & 11.79 \\
\hline $\mathbf{M g O}$ & 9.96 & 8.35 & 5.19 & 5.87 & 7.42 & 6.87 & 6.23 \\
\hline $\mathbf{C a O}$ & 7.20 & 8.16 & 9.772 & 9.001 & 9.863 & 9.858 & 14.62 \\
\hline $\mathbf{H}_{\mathbf{2}} \mathbf{O}$ & 5.18 & 3.63 & 1.39 & 1.75 & 2.39 & 2.29 & 2.11 \\
\hline $\mathbf{T i O}_{\mathbf{2}}$ & 1.51 & 1.27 & 1.39 & 1.58 & 1.29 & 1.19 & 1.39 \\
\hline $\mathbf{N a}_{\mathbf{2}} \mathbf{O}$ & 1.2 & 1.61 & 2.13 & 2.19 & 1.62 & 1.67 & 1.61 \\
\hline $\mathbf{K 2 O}$ & 0.82 & 0.99 & 0.692 & 0.638 & 0.482 & 0.458 & 0.464 \\
\hline $\mathbf{P}_{\mathbf{2}} \mathbf{O}_{\mathbf{5}}$ & 0.15 & 0.19 & 0.146 & 0.149 & 0.124 & 0.113 & 0.119 \\
\hline $\mathbf{M n O}$ & 0.07 & 0.09 & 0.184 & 0.177 & 0.164 & 0.161 & 0.178 \\
\hline $\mathbf{T o t a l}$ & 98.858 & 98.4397 & 99.734 & 99.785 & 100.383 & 98.353 & 99.591 \\
\hline $\mathbf{V}$ & 300 & 260 & 270 & 310 & 280 & 260 & 300 \\
\hline $\mathbf{C r}$ & 263 & 258 & 258 & 220 & 288 & 331 & 355 \\
\hline $\mathbf{S r}$ & 254 & 247 & 176 & 184 & 178 & 175 & 246 \\
\hline $\mathbf{B a}$ & 220 & 250 & 210 & 220 & 130 & 130 & 200 \\
\hline $\mathbf{Z r}$ & 145 & 141 & 139 & 129 & 112 & 105 & 152 \\
\hline $\mathbf{C l}$ & 130 & 086 & 239 & 150 & 110 & 130 & 250 \\
\hline $\mathbf{W}$ & 120 & 430 & 480 & 650 & 570 & 260 & 480 \\
\hline $\mathbf{C u}$ & 088 & 035 & 150 & 120 & 180 & 170 & \\
\hline $\mathbf{N i}$ & 65 & 51 & 51 & 49 & 68 & 65 & 81 \\
\hline $\mathbf{C o}$ & 55 & 62 & 51 & 54 & 60 & 49 & 52 \\
\hline $\mathbf{C e}$ & 46 & 49 & 43 & & & 37 & \\
\hline
\end{tabular}




\begin{tabular}{|c|c|c|c|c|c|c|c|}
\hline Sc & 44 & 29 & 35 & 4 & 43 & & \\
\hline $\mathbf{Z n}$ & 35 & 44 & 89 & 91 & 86 & 84 & 110 \\
\hline $\mathbf{Y}$ & 20 & 23 & 21 & 18 & 2 & 16 & 19 \\
\hline $\mathbf{H f}$ & 17 & 22 & 21 & 14 & 16 & 17 \\
\hline $\mathbf{G a}$ & 16 & 14 & 15 & 16 & 17 & 23 \\
\hline Rb & 15 & 13 & 11 & 8.4 & 7.6 & 8.7 & 9 \\
\hline Ta & 13 & 33 & 24 & 16 & 13 & 16 & 24 \\
\hline Nd & - & - & - & - & - & - & - \\
\hline Pb & & & 46 & & & & \\
\hline
\end{tabular}

\section{References:-}

1. Ait chayeb, E. H., Youbi, N., El-Boukhari, A., Bouabdelli, M. and Amrhar, M. (1998) : Le volcanisme permien et mésozoïque inférieur du bassin d'Argana (Haut Atlas occidental, Maroc): un magmatisme intraplaque associé à l'ouverture de l'Atlantique central. Journal of African Earth Sciences, 26, 499-519.

2. Bébien, J. (1980) : Magmatismes basiques dits «orogéniques» et «anorogéniques» et teneurs en Ti02: les associations "isotitanées" et "anisotitanées". Journal of Volcanology and Geothermal Research, 8: 337-342.

3. Bensalah, M.K., Youbi, N., Mahmoudi, A., Bertrand, H., Mata, J., El Hachimi, H., Madeira, J., Martins, L., Marzoli, A., Bellon, H., Medina, F., Karroum, M., Karroum, L.A. and Ben Abbou, M. (2011) : The Central Atlantic Magmatic Province (CAMP) volcanic sequences of Berrechid and Doukkala basins (Western Meseta, Morocco). Volcanology and Geochemistry: Comunicações Geológicas, 98, 15-27.

4. Bertrand, H. and Westphal, M. (1977) : Comparaisons géologiques et paléomagnétiques des tholeiites du Maroc et de la cote orientale de l'Amérique du Nord: implication pour l'ouverture de l'Atlantique. Bulletin de la Société Géologique de France, 7, XVX, 3, 513-520.

5. Bertrand, H., Dostal, J. and Dupuy, C. (1982) : Geochemistrey of Early Mesozoic Tholeiites from Morocco. Earth and Planetary Sciences Letters, 58, 225-239.

6. Bertrand, H. (1991): The Mesozoic tholeiitic province of Northwest Africa: a volcano-tectonic record of the early opening of Central Atlantic. In: Magmatism in extentional structural settings (Edited by Kampunzu, A. B. and Lubala, R. T.), Springer-Verlag, Berlin, Heidelberg, 147-188.

7. Besson, M. and Fonteilles, M. (1974) : Relation entre les comportements contrastés de l'alumine et du fer dans la différenciation des séries tholéitiques et calco-alcalines. Bulletin de la Société Française de Minéralogie et de Cristallographie, 97, 445-449.

8. Callegaro, M., Baker, R., Bethlehem, J., Goritz, A.S., Krosnick, J.A. and Lavrakas, P.J. (2014): Online panel research: History, concepts, applications a look at the future. In M. Callegaro, R. Baker, J. Bethlehem, A.S. Goritz, J.A. Krosnick and P.J. Lavrakas (Eds.). Online Panel Research: A Data Quality Perspective (1-22). United Kingdom: Wiley \& Sons, Ltd.

9. Charière, A. (1990) : Héritage hercynien et évolution géodynamique alpine d'une chaîne intracontinentale : le Moyen Atlas au SE de Fès (Maroc). Thèse de doctorat Es-Sciences, Université Paul Sabatier, Toulouse III, 589 p.

10. Cogney, G., Termier, H. and Termier, G. (1971). Sur la présence de "pillow-lavas" dans le basalte du PermoTrias au Maroc central. Comptes Rendus de l'Académie des Sciences, Paris, 273 p.

11. Cogney, G., Normand, M., Termier, H. and Termier, G. (1974): Observation sur le basalte du basin triasique de Rommani-Maâziz (Maroc occidental). Notes et Mémoires du Services Géologique, Maroc, 264, 153-173.

12. Cogney, G. and Faugères, J. C. (1975) : Précisions sur la mise en place des épanchements basaltiques des formations triasiques de la bordure septentrionale du Maroc Central. Bulletin de la Société Géologique de France, 17, 721-733.

13. De Pachtère, P., Bertrand, H. and Tane, J.L. (1985) : Mise en évidence de centres d'émission dans la série volcanique fini-triasique du Haut-Atlas de Marrakech (Maroc). Compte Rendu de l'Académie des Sciences, Paris, 300, II, 20, 1029-1032.

14. El Attari A. (2001): Etude Lithostratigraphique et Tectonique des Terrains Cambro - Ordovicien du Môle côtiers (Meseta Occidental, Maroc). Thèse d'état. Rabat : Université Mohammed V, Rabat. 389 p.

15. El Hachimi, H., Youbi, N., Madeira, J., Bensalah, M.K., Martins, L., Mata, J., Bertrand, H., Marzoli, A., Medina, F., Munhá, J., Bellieni, J., Mahmoudi, A., Ben Abbou, M. and Assafar, H. (2011) : Morphology, internal architecture, and emplacement mechanisms of lava flows from the Central Atlantic Magmatic Province (CAMP) of Argana basin (Morocco). In: Van Hinsbergen, D. J. J., Buiter, S., Torsvik, T. H., Gaina, C., Webb, 
S. (Eds.) Out of Africa - a synopsis of 3.8 Ga of Earth History. The Geological Society of London Special Publication, 357, 167-193.

16. El Wartiti, M. (1981): Les terrains permo-carbonifères et leur couverture dans la région de Tiddas-Souk Es Sebt des Ait Ikkou (Maroc central). Thèse 3ème cycle, Rabat, Maroc, 193p.

17. Farki, K., Zahour, Gh., El Hadi, H., Alikouss, S. and Zerhouni, Y. (2014) : Les tholéiites fini-triasiques de Mohammedia (Meseta côtière, Maroc) : Témoins d'un volcanisme de rift intracontinental avorté. European Scientific Journal, 10, 20, 125-143.

18. Fiechtner, L., Friedrichsen, H. and Hammerschmidt, K. (1992): Geochemistry and geochronology of Early Mesozoic tholeiites from central Morocco. Geologische Rundschau 81, 1, 45-62.

19. Font, E., Youbi, N., Fernandes, S., El Hachimi, H., Kratinová, Z. and Hamim Y. (2011) : Revisiting the magnetostratigraphy of the Central Atlantic Magmatic Province (CAMP) in Morocco. Earth and Planetary Science Letters, 309, 3-4, 302-317.

20. Gigout, M. (1956): Recherche sur le Pliocène et Quaternaire atlantique marocaine. Travaux de l'Institut Scientifique Chérifien, Série Géologie Dynamique et Géographie Physique, 5-91 pp.

21. Gill, J.B. (1981): Onogenic andesite and plate tectonics. Springer-Verlag, Berlin, 390 p.

22. Girard, D. (1987): Géochimie et minéralogie des laves triasiques de la Meseta Côtière. Bulletin de l'Institut Scientifique de Rabat, 11, 37-46.

23. Girard, D., Bellon, H. and Maury, R.C. (1989): Géochimie, datations et épisode hydrothermal du volcanisme triasique de la Meseta côtière marocaine. Colloque de Géologie Franco-Marocain, Strasbourg, France, 116.

24. Hamidi, E.M., Boulangé, B. and Colin, F. (1997) : Altération d'un basalte triasique de la région d'El Hajeb, Moyen Atlas, Maroc. Journal of African Earth Sciences, Vol. 24, 1/2, 141-151.

25. Hminna, A., Saber, H., Schneider, J.W., Klein, H. and Voigt, S. (2008): First trace fossil in Sidi Saïd M'aachou basin (coastal meseta, morocco): Paleoenvironnement and sedimentology. 20ème colloque des bassins sédimentaires marocains (Oujda, Maroc), May 21-23, 2008, 36-40.

26. Hminna, A., Saber, H., Schneider, J.W., Klein, H., Voigt, S. and Hmich D. (2009) : Brachychirotherium ichnofauna from the Upper Triassic of Oued Oum Er Rbiaa Formation of Sidi Saïd M'aachou basin, Coastal Meseta, Morocco. First International Congress on North African Vertebrate Palaeontology, Abstracts, p. 32.

27. Hminna, A. (2013) : La limite Permien supérieur - Trias du Bassin d'Argana (Haut-Atlas) et le Trias supérieur du Bassin de sidi Saïd Maachou (Meseta Occidentale) (Maroc) ; Biostratigraphie, Sédimentologie, Tectonique et Géochimie. Thèse de doctorat de l'Université Chouaïb Doukkali, El Jadida, Maroc. 255 p.

28. Hminna, A., Voigt, S., Klein, H., Saber, H., Schneider, J.W. and Hmich, D. (2013): First occurrence of tetrapod footprints from the continental Triassic of the Sidi Saïd Maachou area (Western Meseta, Morocco). Journal of African Earth Sciences, 80, 1-7.

29. Irvine, T.N. and Baragar W.R.A. (1971): A guide to the chemical classification of the common volcanic rocks. Canadian Journal Earth Sciences 8, 523-248.

30. Knight, K.B., Nomade, S., Renne, P.R., Marzoli, A., Bertrand, H. and Youbi, N. (2004): The Central Atlantic magmatic province at the Triassic-Jurassic boundary: paleomagnetic and 40Ar/39Ar evidence from Morocco for brief, episodic volcanism. Earth and Planetary Science Letters, 228, 143-160.

31. Kuno, H. (1968): Differentiation of basalt magmas. In: Hess, H.H., Poldervaart, A. (Eds.), The Poldervaart Treatise, on Rocks of Basaltic Composition, Vol. 2. Insterscience Publishers, pp. 623-688.

32. Lachkar, G., Ouarhache, D. and Charrière, A. (2000) : Nouvelles données palynologiques sur les formations sédimentaires associées aux basaltes triasiques du Moyen Atlas et de la haute Moulouya (Maroc). Revue de Micropaléontologie, 4, 281-299.

33. Le Maitre, R.W., Bateman, P., Dudek, A., Keller, J., Le Bas, M.J., Sabine, P.A., Schmid, R., Sorensen, H., Streckeisen, A., Woolley, A.R. and Zanettin, B. (1989) : A classification of igneous rocks and glossary of terms. 208p. Balckwell Scientific Publications, Oxford.

34. Lyazidi, A., El Wartiti, M. and Fadli, D. (2003) : Evolution Géodynamique du bassin triasique de Berrechid EL Gara - Benslimane géométrie des dépôts (Meseta Nord Occidentale, Maroc). Pangea, 39/40, 23-36.

35. Mahmoudi, A. and Bertrand, H. (2007) : Identification géochimique de la province magmatique de l'Atlantique central en domaine plissé: exemple du Moyen Atlas marocain. Comptes Rendus Géoscience, 339, 545-552.

36. Marzoli, A., Renne, P.R., Peccerillo, E.M., Ernesto, M., Bellieni, G. and De Min, A. (1999) : Extensive 200million-year-old continental flood basalts of the Central Atlantic magmatic province. Science, 23, 284, 616618.

37. Marzoli, A., Bertrand, H., Knight, K.B., Cirilli, S., Buratti, N., Vérati, C., Nomade, S., Renne, P.R., Youbi, N., Martini, R., Allenbach, K., Neuwerth, R., Rapaille, C., Zaninetti, L. and Bellieni, G., (2004) : Synchrony of the Central Atlantic magmatic province and the Triassic-Jurassic boundary climatic and biotic crisis. Geology 32, 
973-976.

38. Meschede, M. (1986): A method of discrimination between different types of mid-ocean ridge basalts and continental tholeites with the Nb-Zr-Y diagram. Chemical Geology 56, 207-218.

39. Miall, A.D. (1996): The Geology of Fluvial Deposits. Sedimentary Facies, Basin Analysis, and Petroleum Geology. Springer-Verlag, Berlin Heidelberg, 582 p.

40. Mullen, E.D. (1983): MnO-P2O5-TiO2: a major element discriminant for basaltic rocks of environments, and its implication for petrogenesis. Earth and Planetary Sciences Letters, 62, 53-62.

41. Miyashiro, A. (1974): Volcanic rocks series in island arcs and continental margin. American Journal of Science, 274, 321-355.

42. Miyashiro, A. (1978): Nature of alkalic volcanic rock series. Contributions to Mineralogy and Petrology, Heidelberg, 66, 91-104.

43. Nockolds, S.R. and Allen, R. (1956): The geochemistry of some igneous rock series-III. Geochimica et Cosmochimica Acta, 9, 34-77.

44. Ouadia, M. (1998) : Les formations Plio-Quaternaiore dans le domaine mesetien occidental entre Casablanca et Safi : Géomorphologie, Sédimentologie, Paléoenvironnements Quaternaires et Evolution actuelle. Thèse d'état es-sciences. Université Mohamed V, Rabat, 319 p.

45. Ouarhache, D. (2002) : Sédimentation et volcanismes (effusif et explosif) associés au rifting triasique et infraliasique dans le Moyen Atlas sud-occidental et la Haute Moulouya (Maroc). Thèse d'état, Université Mohammed V, Rabat, $282 \mathrm{p}$.

46. Pearce, J.A. (1980) : Geochimical evidence for the genesis and eruptive setting of lava from Tethyan ophiolites. In: A. Panayiotou (Editor), Proceeding International Ophiolite Symposium. Nicosia, Cyprus, 261-272.

47. Peccerillo, A. and Taylor, S.R. (1976): Geochemistry of Eocene calc-alkaline volcanic rocks from the Kastamonu area, northern Turkey. Contributions to Mineralogy and Petrology, 58, 63-81.

48. Peretsman, G. (1985): Geochemichal and petrographic analysis of Early Mesozoic evaporites from Morocco: implications for the evolution of the North Atlantic rift. Master Thesis, Oregon University (U.S.A.), 86 p.

49. Peretsman, G. and Holser, W.T. (1988): Geochemistry of Moroccan evaporites in the setting of the North Atlantic Rift. Journal of African Earth Sciences, 7, 375-38.

50. Termier, H. and Termier, G. (1948) : Observations nouvelles sur le Permo-Trias et la base du Lias dans le Maroc central et le Moyen Atlas septentrional. Bulletin de la Société Géologique de France, 5, 18, Fasc. 6-7, $395-405$.

51. Saber, H., Hminna, A., Schneider, J.W. and Hmich, D. (2007) : First Record of Triassic Arthropod Ichnia in the Sidi Saïd Maachou Basin (Coastal Meseta, Morocco): Wissenschaftliche Mitteilungen des Institutes für Geologie der TU Bergakademie Freiberg, 36, 117-119.

52. Verati C., Rapaille, C., Feraud, G., Marzoli, A., Bertrand, H., and Youbi, N. (2007) : 40Ar/39Ar ages and duration of the Central Atlantic Magmatic Province volcanism in Morocco and Portugal and its relation to the Triassic-Jurassic boundary. Palaeogeography, Palaeoclimatology, Palaeoecology, 244, 308-325.

53. Verdier, J. (1971) : Etude géologique des basaltes doléritiques du Trias du barrage de Moulay-Youssef au site des Aït Aadel sur 1'Oued Tassaout, Haut Atlas, Maroc. Notes et Mémoires du Service Géologique, Maroc, 31, 237, 241-272.

54. Winchester, J.A. and Floyd, P.A. (1976): Geochemical magma type discrimination: Application to altered and metamorphosed basic igneous rocks: Earth and Planetary Science Letters, 28, 459-469.

55. Youbi, N., Martins, L.T., Munhá, J.M., Ibouh, H., Madeira, J., Ait Chayeb, H. and El Boukhari, A. (2003): The Late Triassic-Early Jurassic Volcanism of Morocco and Portugal in the Framework of the Central Atlantic Magmatic province: An Overview. In: Hames W. E., Machone J. G., Renne P.R., Ruppel C. (Eds.), The Central Atlantic Magmatic Province: Insights from Fragments of Pangea. American Geophysical Union Geophysical Monograph Series, 136, 179-207. 